\title{
"Reward comes, when you are not there". The image of Catholicism and Buddhism in the TV Series Siła wyższa [Higher Power] by Wojciech Adamczyk
}

\author{
Łucja Demby (D) https://orcid.org/0000-0001-8786-9849 \\ Institute of the Audio-Visual Arts \\ Jagiellonian University \\ lucja.demby@uj.edu.pl
}

\begin{abstract}
The paper by Łucja Demby discusses the television series Siła wyższa [Higher Power], first broadcast on Polish TVP1 public television in 2012. The series was directed by Wojciech Adamczyk, familiar to viewers as the creator of the extremely popular TV series Ranczo [The Ranch]. Higher Power, in a comedic convention, depicts the confrontation between Franciscan monks and the residents of a nearby Buddhist centre. Łucja Demby points to Wojciech Adamczyk's trademarks present in the series (notable also in The Ranch and the director's other work), such as including a message of tolerance and understanding between people of different persuasions. The author also points out how the series draws on religious stereotypes functioning in Polish society, concerning both the dominating Catholicism and other religions. In terms of composition, the paper is based around two quotes: a statement by Lama Rinchen regarding the possibility of dialogue between Catholicism and Buddhism, and a fragment from a book by Pope John Paul II, emphasizing the differences between these two religions.
\end{abstract}

Keywords: Buddhism, Catholicism, TV series, Wojciech Adamczyk

Słowa kluczowe: buddyzm, katolicyzm, serial telewizyjny, Wojciech Adamczyk

In the fourth episode of Higher Power (Revolt at the Monastery), there is a scene crucial for the analysis of the whole series. The Buddhist master Ga, in an act of protest against the Franciscans who had sent one of their brothers to spy on him, sits in a meditative posture in front of their monastery and remains there, a silent elephant in the room. The guardian Father Jan, alarmed by the monks, arrives to react to this 
demonstration, but instead of chasing the intruder away, he kneels down beside him, makes the sign of the cross, and remains silent. In this meditation, they are accompanied by a small white dog - a "little brother" according to the Franciscans. When the devastated father Robert - the unfortunate "spy" - starts begging the two clerics for forgiveness, the superior replies calmly: "Come on, son. It's something else we are talking about here." The Buddhist master completes this statement with the words: "Two old monks - no need for words."

This scene highlights, in metaphorical shorthand, the message accompanying not only Higher Power, but also other TV series by Wojciech Adamczyk, written by Robert Brutter, ${ }^{1}$ with The Ranch at the forefront. It is essentially a message of love expressed in the formula: do not argue, let go of hatred and prejudice against others, and notice how much alike you are, despite the apparent differences. Although these words may seem naïve, they in fact concern some fundamental issues: those of appropriate interpersonal relations and proper spiritual development of individuals, but also of opportunities for dialogue between ideas that those individuals uphold, as well as between religions, in this case between Buddhism and Christianity.

The described scene is crucial for another reason; in a condensed way, it contains a few elements that are extremely important for the series, largely determining its specificity and its potential interpretation. Evident here is, above all, the silence, the tranquillity, contrasted much later (in episode 13, The Miracle) to the "European chatter," but present throughout the series as an ideal to be pursued by both the Buddhist and the Christian communities. This silence is paradoxically accompanied by dialogue and understanding. The iconographic layer, making, among other things, the image of meditating monks so memorable, emphasizes diversity, expressed through clothing: the brown habit of the Franciscan and the colourful robe of the Buddhist. However, it is notable that this difference, so clearly marked at first, turns out to be only apparent in the end. The nature of the whole meditation scene, the participation of a dog - the pet of Dorota, a guest at the order - the attitudes of the other characters, all clearly point to the comedic aspect of the series. The matters taken up are important, yet they are presented in a tongue-in-cheek manner. In spite of this comedic convention, the described scene in episode 4 can be regarded as symbolic, a visual equivalent of a question that seems to be the theme of the whole series: is dialogue between Catholics and Buddhists possible?

"Of course, we can talk about dialogue only if the will to engage in it is expressed by both parties," says Lama Rinczen in a lecture given during a conference at the John Paul II Catholic University of Lublin, "Based on my personal experience, I can say that I encounter such willingness in some Catholic environments. These are

${ }^{1}$ The TV series was first broadcast on TVP1 in 2012, after the success of six seasons of The Ranch. The Ranch was initially written by Jerzy Niemczuk and Robert Brutter (writers for Higher Power), and from the seventh season onward, by the latter alone. Like The Ranch (and the later Girls from Lviv, 2015), Higher Power is based on the idea of outsiders appearing in a community and changing the way the protagonists think. In Higher Power, those outsiders are Buddhists conducting courses at a newly established centre. The Franciscans, until recently the only guardians of the souls in the area, also conduct a "course on moral renewal" for politicians. All three seasons, due to the same director, screenwriter, and similar compositional structure, are clearly original. 
mostly academic and monastic circles. The former - probably due to natural scientific curiosity. Considering that among all religions, Buddhism is perhaps most based on monastic structure and, apart from Christianity, was the only one to develop a full monastic system, a search for dialogue at this level also seems completely natural. It is noteworthy that, despite significant philosophical and theological differences, the Christian-Buddhist dialogue is developing extremely easily and constantly. This is probably because, just as charity plays a key role in the teaching of Christ, so love and compassion are the essence of the Buddha's teaching."

The speaker of these words draws attention to the similarity between both religions (which, by the way, is not yet a guarantee of dialogue between them). A different position is found, in this statement of John Paul II in the document Nostra aetate, noting that, despite some apparent analogies, Christianity is fundamentally different from Buddhism:

"It's common to refer to Christian mystics here, either to those from Northern Europe (Eckhart, Tauler, Suzo, Ruysbroeck), or to the later Spanish mysticism (Saint Theresa of Avila and Saint John of the Cross). However, if John of the Cross, in his Ascent of Mount Carmel and in Dark Night of the Soul, speaks of the need for purification, and for detachment from the sensual world, this detachment is not an end in itself. [...] Classic texts of John of the Cross are sometimes understood in the Asian East as a confirmation of the ascetic methods applied there. However, the Doctor of the Church does not propose a mere detachment from the world. He proposes to break away from the world to unite with what is transcendent, and what is transcendent is not nirvāna, it is a Person, God. And the union with Him is realized not through purification alone, but thorough love."

In Wojciech Adamczyk's TV series, reconciliation between religious camps also takes place through love, yet understood slightly differently, in line with the entertainment formula of the show, and in a manner satisfactory to mass audiences (for whom the main theme of the series is already a difficult trial). Urszula, a devout Buddhist, falls for a Catholic man (not very zealous in his practice) and temporarily abandons Master Ga (although she becomes a monk eventually); Dorota, living at the Franciscan monastery, finds love with the founder of the Buddhist centre, Tomek; and even the master himself falls in love - "platonically, but deeply" - with sister Bazylia. Religious problems are clearly of secondary importance compared to the romantic trials and tribulations of the characters, but they are so broadly present in the series that it would be difficult to disregard them.

The parallel presence of Buddhist and Catholic threads is marked in Higher Power consistently from the beginning. The mandala, the cross, and the images of a Buddhist and a Franciscan monk interweave in the opening credits. The culmination is the image of a monastery and a church, against which a Buddha statue emerges in

${ }^{2}$ Lama Rinczen, Dialog międzyreligijny z punktu widzenia buddyzmu, [in:] Pokój dla świata. Znaczenie dialogu międzyreligijnego (w kontekście „Deklaracji o stosunku Kościoła do religii niechrześcijańskich Nostra aetate Soboru Watykańskiego II") dla społeczności polskiej i ukraińskiej oraz Kościoła w Europie Środkowowschodniej (1965-2005), S.J. Żurek (ed.), Lublin 2006, pp. 47-54.

3 Jan Paweł II, Przekroczyć próg nadziei, Lublin 1994, p. 78. 
the foreground. In the first episode, this effect is amplified by the appearance of the title, Buddhist Thunderbolt, against the monastery buildings. The opening scenes are constructed in a similar way and are amplified by stereotypical representations of the characters representing the competing systems of belief. This stereotyping should be noted at the outset, to avoid a deceptive path of interpretation, where in mere convention we would seek a consistent representation of the actual religious communities. Despite its attempt at reflection, Higher Power is a comedy, playing with the stereotypes embedded in the collective consciousness. This intent is expressed already at the beginning of the first episode through iconographic elements. "Iconography, just like a familiar plot and stereotypical characters, provides a stenographic record of mutual communication reconnaissance," "writes Thomas Sobchack. "Neither the creator nor the viewer need to think: the jungle is treacherous, the castle or the dark tower above the village are ominous, the flat horizon of the desert is unyielding. Capes and evening clothes indicate a threat to the character (unless it's a musical), laboratories with mysterious concoctions are occupied by people who conduct inhumane experiments." 5

In Higher Power, "being Buddhist" is invariably suggested by the image of multicoloured prayer flags in the centre's front yard, while the monastery and its inhabitants are presented in a way to evoke associations with the Middle Ages: old dilapidated walls, harsh cells, and monks' outfits. As Erwin Panofsky rightly pointed out, the characters' behaviour also usually corresponds to the iconography. ${ }^{6}$ This correspondence is evident even in the way the characters speak; when the guardian father states that the "infidels" are a "scourge," he expresses his decision to go and convert them as follows: "Tedy idźmy" ("Let us tread, therefore"). Katarzyna Wiśniewska writes: "At times, the monks [...] seem as if taken out of a landscape, poor, living in a dilapidated monastery somewhere in the country, driving a piece of junk which they refuse to repair, because it's enough to just tune yourself to the car. In addition, they speak what is almost Old Polish." The unrealistic image of monks meditating in a dilapidated monastery and maintaining minimal contact with the world, stands out among other Polish series on this subject. "The nuns run missions and work in hospitals in Africa (Klan [Clan], Samo życie [That's life]), run a hospice (Klan), a centre for mentally handicapped children (Pensjonat Pod Róża [Pension under the Rose]), a community club (Klan), an orphanage [...], monks are volunteers at a children's oncology ward, support a retirement home, and save the institution from closing down (Galeria [Gallery])" - writes Beata Łaciak, analysing the image of the clergy

${ }^{4}$ T. Sobchack, A Classical Experience, [in:] Film Genre. Theory and Criticism, B.K. Grant (ed.), London 1977, s. 45.

${ }_{5}^{5}$ Quote: A. Ćwikiel, Próba opisu ikonograficznego filmów science fiction, [in:] Zagadnienia interpretacji dzieła filmowego, J. Trzynadlowski (ed.), Wrocław 1986, p. 194.

${ }^{6}$ See E. Panofsky, Styl i medium w filmie, transl. J. Mach, [in:] Estetyka i film, A. Helman (ed.), Warszawa 1972, p. 139.

${ }^{7}$ K. Wiśniewska, ,Siła wyższa” przykuwa do ekranu, "Gazeta Wyborcza” 2012, no. 268, p. 8. It is worth noting that this is actually the only existing review of the series, which has not been thoroughly analysed, until now, although it certainly deserves it. 
in Polish dramatic series. ${ }^{8}$ In the world of Higher Power- simplified purposefully, partly for comedic purposes, partly to make the theses put forward in the series stand out - the monks only pray and fight with the followers of other religions. Their day is filled with Matins, the reading of the Holy Bible, meditation, daytime prayers, the Holy Mass, Vespers, Compline and the Jasna Góra Appeal (all these activities are listed in the third episode of the series, Kidnapping).

A careful examination of the opening and final shots of the series exposes the compositional bracket capturing the film's structure, and helps in understanding the point of view from which the entire narrative is conducted. Seemingly, both threads, Buddhist and Catholic, are not only parallel but equivalent; at times, one may even get the impression that the creators take the side of Buddhism, with its openness and tolerance. However, the series is in fact aimed at the Catholic viewer, and it is from this point of view that the whole story is told. This vantage point is suggested at the outset by the establishing shot of episode 1, or rather by the establishing shots, as the beautifully framed beginning of the series establishes the setting through a montage of tasteful photos. The monastery is first shown in the distant background, and then in ever closer grounds, with close-ups and details, among which the first frame depicts a small bird sitting on the head of a statue. In addition to the obvious informational function of these shots (the action takes place at a Catholic monastery), we are undoubtedly dealing with one of those moments of pure, poetic beauty that sometimes appear in films, regardless of their content. From the mood of radiant poetics, however, we quickly move to the dark interior of the monastery, where a brother vigilans walks down the corridor, ringing a bell and shouting Benedicamus domino, to start the day "from praising God for a good night and for the next day of life received from Him as a gift." The diverse reactions of the brothers to the Franciscan wake-up call introduce the ubiquitous comic element in the series. The Buddhist thread is initiated a little later and is clearly secondary to the events taking place at the Franciscan monastery, becoming a hindrance to their Catholic life, and a clear challenge to remove this hindrance.

The ending of Higher Power also takes place in the monastery: the monks say goodbye to the politicians whom they have hosted during a course on moral renewal, are surprised to find money from them, and are informed by sister Bazylia that there will be more courses. The Buddhist thread ends much earlier, it is difficult to even say when, because the participants in the course at the Mala centre quickly express a lack of interest in what Master Ga wants to convey to them. Money is their real god - as the latter rightly notes - and stock market activity is what gives their lives meaning. As well, the characters of Master Ga and his main helpers Urszula and Tomek are reduced almost exclusively to romantic themes and emotional entanglements with their paramours. Admittedly, Urszula concludes that her love for a man was only a step on her path of spiritual development, and decides to become a Buddhist nun, but her decision is devoid of any deeper context of a strictly religious nature. It functions rather

${ }^{8}$ B. Łaciak, Kwestie społeczne w polskich serialach obyczajowych-prezentacje i odbiór. Analiza socjologiczna, Warszawa 2013, p. 80.

9 Prenowicjat franciszkanów prowincji św. Antoniego i bt. Jakuba Strzemię, http://www.prenowicjat. franciszkanie.pl/pl/nasz-dzien/benedicamus-domino [access: 25.10.2018]. 
as a rhetorical device providing an interesting conclusion to the story of impossible love between two people. Higher Power, despite the seemingly Buddhist themes, is therefore a series told from a Catholic point of view, and intended for Catholics. The Buddhist thread is important here; it allows the viewer - accustomed to the "obvious" world of the culture they grew up in - to learn tolerance and openness towards what is different. In a somewhat exaggerated way (unsurprising in light of the series' comedic convention), such a model viewer is embodied, at the intratextual level, by Sister Bazylia. Initially distrustful and even hostile towards the "dissenters," she befriends Master Ga, learns to drink green tea, and acknowledges with amazement that Buddhists have a "rosary" ( $m \bar{a} l \bar{a})$ and that many important things happened in the world before Christ. The culmination of this transformation is undoubtedly the scene where sister Bazylia addresses some female visitors from the school, saying: "What do you want from those decent Buddhists?" The degree of "enlightenment" of the endearing nun is, of course, superficial and humorous. Most important here, however, is the change in her way of thinking, her openness to a foreign religion and culture. Causing such change is the rationale for the Buddhist thread in the series in the first place. Higher Power is not addressed to Buddhists or people considering conversion. It is meant for the average Polish viewer (often a Catholic, though not necessarily ${ }^{10}$ ), to teach them a different way of thinking. A stereotypical representation of Buddhists and Franciscan friars may seem naïve and superficial ${ }^{11}$ to more educated viewers, but it is definitely just a pretext. Higher Power is not a treatise on Buddhism, but a comedy meant to open human minds. For this purpose, it initiates identification processes that enable the viewer to undergo such transformation by identifying with the protagonists. The monks of Higher Power, from whose point of view the Buddhist centre is presented over and over again, undergo a significant evolution of views and attitudes towards the followers of a different religion. Katarzyna Wiśniewska writes about this in the quoted review:

It all gets even more Polish when time comes to kick the "dissenters" - Buddhists running meditation courses - out of the neighbourhood. Religious phobias surface among the brethren: "If a Hindu or a Tibetan is fooled by Buddhism, that's understandable. By why did you, progeny of Catholic soil, turn away from true faith?" The most hard-headed friar says: "It is a serious sin to do something to an infidel, but also common benefit." In the end, there is a ceasefire; the monastery and the centre enter into "ecumenical cooperation." The Buddhist master and a monk jointly answer the students' questions regarding "the meaning of life." That's something you don't experience in real life: the real Church still has a problem with accepting other religions and not treating them as faiths of lesser kind. ${ }^{12}$

10 "And yet, on Sunday evenings, several million Poles (with definitely much less zealous Catholics among them) sit in front of TV sets and watch Higher Power" - writes Katarzyna Wiśniewska. See K. Wiśniewska, op. cit., p. 8.

${ }^{11}$ Despite a careful specialist consultation on purely technical matters, the rather simplified version of Buddhist monasticism presented in the series may raise doubts. The same applies to combining elements belonging to various Buddhist schools. This problem was solved in Higher Power in a very simple way. In episode 6 (Well of Reconciliation), Tomek, upon seeing Urszula perform exercises that do not belong to the Buddhist tradition, says to the commissioner: "We are open."

12 K. Wiśniewska, op. cit., p. 8. 
Although the author of these words juxtaposes the fictional world of Higher Power with Polish reality, Wojciech Adamczyk is interested primarily in a reverse process: the impact of the series, as a didactic comedy, on the viewer. The vicissitudes of the characters and the evolution of their views serve this purpose. In the initial episodes of Higher Power, there are many examples of religious reluctance towards the "dissenters." Apart from the excerpts mentioned in the quoted review, it is worthwhile to mention a scene in episode 2 (Blessed Catastrophe), where the Franciscans, having sent brother Robert to the Buddhist centre on a secret mission, pray for his soul. In this comic scene, only the guardian father asks God to protect their brother from the influence of another religion. Brother Wojciech, most relentless in his hatred towards other religions, specifies that the matter concerns a "bad religion," and prays for the "perdition" of Buddhists. As the storyline progresses (and the alleged enemy is encountered, not only imagined based on common stereotypes), the situation changes, partially thanks to the residents of the Buddhist centre themselves, with Master Ga at the helm. Higher Power is a comedy, so the transformation of the relationship between the Franciscans and the Buddhists abides not as much in dramatic twists of plot as in evidently comic situations. Brother Robert unwittingly beginning to perform breathing exercises at the church; Master Ga who, in good faith, recites Hail Mary with sister Bazylia, and having understood the evangelical command to "Feed the hungry" literally comes to the monastery for dinner - all perfectly fit this comedic context. However, as the relationship between the monastery and the Buddhist centre improves and even the breathing exercises lose their "demonic" dimension in the eyes of those of the Catholic Church (As Master Ga explains to Sister Bazylia: "Breathing is not another religion. Breathing is breathing"), the plot gradually touches upon more serious matters. As the characters of Higher Power open up to other religions, a gradual shift towards greater spirituality occurs. A true chasm separates the religious reflections of the friars in the final episodes from their prejudices and judgments expressed at the beginning of the series. The last episodes appeal to the viewer not only with the "ecumenical scene" mentioned in the quoted review, in which Master Ga and brother Robert jointly explain to the participants of the course that it is not "I" that matters, but acting for the good of others. They are also full of reflections on the true face of religion, love and mercy, the sense of life, and duties to God and people. "We strive for God, but does God have any use for us?" asks brother Robert when talking to brother Wojciech, who, as the plot develops, also softens and sheds his uncompromising severity towards sin and otherness.

Higher Power, despite the parallel presentation of, and apparent equivalence of, Buddhist and Catholic themes, presents a clearly Christian viewpoint, and its narrative is rooted in Western European culture. Buddhism is largely reduced to a reservoir of popular iconographic elements (prayer flags, Tibetan monk robes, a Buddha statue, breathing exercises) and terminology (the word samsāra repeated over and over again). Obviously, such imagery surrounding both religions may raise certain doubts and even ideological objections. In this discussion, I am considering Higher Power as a comedy, and as a trademark aspect of Wojciech Adamczyk's portfolio. However, the series could also be subjected to a thorough ideological analysis. It 
is also noteworthy that the alleged conflict between the two religions has been presented in a smoothed-out manner, appropriately for the comedic convention. Even the choice to counterweight Catholicism with Buddhism, underrepresented in Poland in comparison to Islam, for example, shows that the problems presented in the comedy are quite removed from reality. The "safe" variation of religious conflict dealt with in Higher Power is an outcome of the series being produced and broadcast by public television, and intended for broad masses, the so-called average viewers, quite attached to their traditions and religion.

This, however, is not something to find fault with, since the series was conceived as a comedy and, within this framework, was executed splendidly. The clash of two different religious attitudes gives, above all, the opportunity for countless comic effects. In the meantime, however, the creators managed to smuggle in some important truths - ones that are more easily assimilated by a viewer who is amused than by one subjected to obtrusive didacticism. Wojciech Adamczyk's grin is not malicious, but warm and full of kindness, and he himself has repeatedly stated that the Enlightenment formula of "teaching through amusing" is close to his heart. Even the most satirically portrayed characters, politicians completely impervious to the influence of any religion, are depicted in Higher Power with tongue firmly in cheek, and in the end they suddenly make the human gestures - surprising for their profession - of selflessly offering the money so needed by the friars, and helping a colleague from another party.

Regarding the opinions quoted above, those of John Paul II and Lama Rinchen, any attempt to answer the question of which of is correct is doomed to fail when considering Higher Power. Agreement between two religions is possible, but on what terms and at what price? The question arises whether it is possible only in comedy, in a non-serious convention, and only when the feelings of people in love come to the fore. In applying his entertainment formula, Adamczyk does not pretend to give a definite answer on the matter of inter-religious dialogue. However, he leaves the viewer hoping that peaceful co-existence and - more broadly - understanding between people is possible. The latter only when selfishness is abandoned. In episode 3 (The Kidnapping), Master Ga gives a short lesson to Adam, extremely resistant to spiritual matters and only interested in stock market levels: "First you always want to be. Reward you want to get. I, I, I, I, I. But reward comes when you are not there. I-samsāra. I is nothing."

The father guardian often speaks in a similar manner, although established on completely different religious assumptions, reminding us that "great things come from self-restraint"; in episode 5 (The Path of the Blind), he also utters these meaningful words regarding the Buddhists: "I want to convince them, and not to destroy them."

Therefore, what builds the bridge between the representatives of different faiths in Wojciech Adamczyk's comedy is broadly understood humanism, and not opting for a particular religion. That is in itself a considerable achievement. 


\section{References}

Higher Power, Feature series, produced by: Polish Television - Film Agency for Program 1, 2011, premiere: 2011, directed by W. Adamczyk, screenplay: R. Brutter, J. Niemczuk, cast: A. Dereszowska, P. Grabowski, P. Fronczewski, K. Dracz, K. Żak et al.

Ćwikiel A., Próba opisu ikonograficznego filmów science fiction, [in:] Zagadnienia interpretacji dzieła filmowego, J. Trzynadlowski (ed.), Wrocław 1986, pp. 193-207.

Jan Paweł II, Przekroczyć próg nadziei, Lublin 1994.

Lama Rinczen, Dialog międzyreligijny z punktu widzenia buddyzmu, [in:] Pokój dla świata. Znaczenie dialogu międzyreligijnego (w kontekście „,Deklaracji o stosunku Kościoła do religii niechrześcijańskich Nostra aetate Soboru Watykańskiego II") dla społeczności polskiej i ukraińskiej oraz Kościoła w Europie Środkowowschodniej (1965-2005), S.J. Żurek (ed.), Lublin 2006, pp. 47-54.

Łaciak B., Kwestie społeczne w polskich serialach obyczajowych - prezentacje i odbiór. Analiza socjologiczna, Warszawa 2013.

Panofsky E., Styl i medium w filmie, transl. J. Mach, [in:] Estetyka i film, A. Helman (ed.), Warszawa 1972, pp. 128-150.

Prenowicjat franciszkanów prowincji św. Antoniego i bł. Jakuba Strzemię, http://www.prenowicjat. franciszkanie.pl/pl/nasz-dzien/benedicamus-domino [access: 25.10.2018].

Sobchack T., A Classical Experience, [in:] Film Genre. Theory and Criticism, B.K. Grant (ed.), London 1977.

Wiśniewska K., ,Siła wyższa” przykuwa do ekranu, "Gazeta Wyborcza” 2012, no. 268, p. 8. 
REDAKTOR PROWADZĄCA

Karolina Wassowska

ADIUSTACJA JĘZYKOWO-STYLISTYCZNA

Justyna Wodzistawska

KOREKTA

Matgorzata Szul

SKŁAD I ŁAMANIE

Hanna Wiechecka

Wydawnictwo Uniwersytetu Jagiellońskiego

Redakcja: ul. Michałowskiego 9/2, 31-126 Kraków tel. 12 663-23-80, fax 12 663-23-83

Druk i oprawa: Drukarnia Eikon 